\title{
"Flameless" oxyfuel combustion development for process improvement, emission reduction in furnaces and incinerators
}

\author{
W. Blasiak ${ }^{1} \&$ J. von Schéele ${ }^{2}$ \\ ${ }^{1}$ School of Industrial Engineering and Management, \\ Royal Institute of Technology (KTH), Sweden \\ ${ }^{2}$ Linde AG, Gas Division, Sweden
}

\begin{abstract}
In recent years, the focus for the development of combustion technology focus has been set on the following main aims: fuel consumption reduction, nitrogen oxides emission reduction, increased productivity and product quality. Fuel consumption reduction has been reduced by as much as $30-40 \%$, and also $\mathrm{CO}_{2}$ emission reduction was achieved by replacing combustion air with oxygen. To achieve very low emission of nitrogen oxides $\left(\mathrm{NO}_{\mathrm{x}}\right)$ the new combustion technology is characterised by: lower temperature of flame, more uniform temperature distribution and reduced concentration of oxygen as well as nitrogen inside the combustion chamber. As in this combustion technique a flame is replaced by a large chemical reaction zone and thus is often not visible the process was named as "flameless" combustion. "Flameless" combustion process that use oxygen, so called oxyfuel combustion, as well as its technical application is the subject of this work. The work presents a description and main features of the "flameless" oxyfuel combustion, results of laboratory tests of a new type of burner, $\mathrm{REBOX}^{\circledR}$, as well as examples of industrial applications including waste incineration are included.

Keywords: oxyfuel combustion, flameless combustion, $\mathrm{NO}_{x}$ reduction, $\mathrm{CO}_{2}$ reduction, incineration improvement
\end{abstract}

\section{Advantages of combustion with use of oxygen enriched air}

Progress in combustion technologies made the use of oxygen for combustion possible in industrial processes drastically reducing $\mathrm{CO}_{2}$ and $\mathrm{NO}_{\mathrm{x}}$ emissions, as 
well as allowing for higher productivity at highest possible level of product quality. Industrial applications of the most advanced product of the oxyfuel technology development, so called "flameless" oxyfuel combustion, are already well documented and provide enormous future potential for this technology in various thermal processes.

Oxygen enrichment of air decreases the amount of nitrogen which is a ballast component in air combustion. In this work for simplicity oxygen enriched air, atmospheric air with higher oxygen content than the standard 21 vol.\%, is called the oxidiser. Since the economy of oxyfuel combustion is dependent on the cost of oxygen, the availability of low cost oxygen is critical to the application economy as well. However, development of lower cost oxygen separation techniques allows at present use of oxidiser with almost $100 \%$ content of oxygen $[1,13]$.

Rising oxygen concentration in the oxidiser leads to:

- higher process efficiency, thus fuel consumption reduction and therefore $\mathrm{CO}_{2}$ emission reduction, Practical experience demonstrates that the thermal efficiency for airfuel installations is found in the interval $25-60 \%$, but for oxyfuel it is $75-90 \%$.

- Higher flame temperature.

- Heat transfer enhancement, thus higher productivity.

- Reduction of $\mathrm{NO}_{\mathrm{x}}$ emission.

\section{Influence of flame properties on heat transfer in heating furnaces}

Change of oxygen content in the oxidiser also influences heat transfer conditions because of changes in flame temperature, in-furnace gas composition, and infurnace gas flow rate generated during combustion and flame volume. An increase of oxygen fraction in the oxidiser changes the flue gas composition rising concentration of components governing the flue gas emissivity but decreasing total amount of flue gases because of lack of nitrogen. Therefore, participation of convective heat transfer in total heat transfer mechanism is slightly reduced in comparison to air combustion. In case of air combustion the main components determining gas emissvity are $\mathrm{H}_{2} \mathrm{O}, \mathrm{CO}_{2}, \mathrm{CO}$ and some fuel molecules. With temperature increase, with the effect of dissociation, another components such as $\mathrm{OH}, \mathrm{H}$ and $\mathrm{O}$ should be also taken into account. It is known that emissivities of gas components vary with wavelength and temperature. Thus, absorption and emission of flue gases takes place in specific ranges of the spectrum [2]. An increase of fraction of radiation by $\mathrm{CO}_{2}$ and $\mathrm{H}_{2} \mathrm{O}$ results in more uniform radiation of the flame. An increase in temperature causes mainly an increase of heat transfer by short wavelengths. Increase of the short wavelength radiation is caused by the presence of $\mathrm{OH}, \mathrm{H}, \mathrm{O}$ and $\mathrm{CH}$.

Heating rate in industrial heating furnaces is a function of the following parameters:

- $\quad$ Flame temperature and its emissivity.

- Flame shape. 
- Firing rate.

- Heat sink temperature, and its emissivity.

- Walls temperature and its emissivity.

A simple overall heat transfer model in the industrial furnace was set up to analyze influence of these parameters on heat flux between flame and heat sink [3].

In this work the flame volume and its emissivity are the main parameters discussed. Flame 5's irradiative characteristics at different firing rates and emissivities are considered as well as the effect on heat sink- and furnace wall temperatures. In this heat transfer model, the furnace volume has been divided into the combustion region (major chemical reaction zone) and the rest of the furnace that is called a 'combustion product region. Therefore, the combustion chamber can be separated as the combination of a well-stirred reactor (reaction zone) and a plug reactor (the reactor zone). Emissivities of heat sink and furnace walls are assumed: $\varepsilon_{\mathrm{s}}=0.8$ and $\varepsilon_{\mathrm{w}}=0.85$ respectively. Heat sink temperature, $\mathrm{T}_{\mathrm{s}}$ is assumed equal to $1000 \mathrm{~K}$ and the furnace wall temperature, $T_{\text {wall }}$ is set equal to $1273 \mathrm{~K}$. In the analysis for simplicity the flame diameter is kept constant.

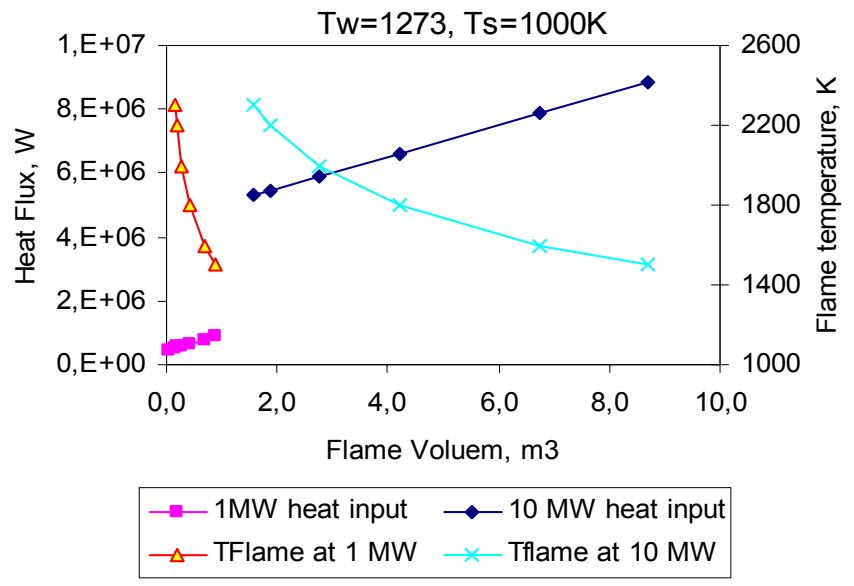

Figure 1: Effects of the flame volume on the net heat flux from the flame to the heated sink for two different heat inputs; $\left(T_{w}=1273 \mathrm{~K}\right.$, $\left.\mathrm{T}_{\mathrm{s}}=1000 \mathrm{~K}, \mathrm{Q}_{\mathrm{o}}=1 \mathrm{MW}\right)[3]$.

\subsection{Flame volume versus heat flux}

In this work, influence of the flame volume on the total heat flux between the flame and heat sink is presented. Effects of the flame volume on the net heat flux at different emissivities of the flame are shown in Figure 1. Heat transfer from the flame to the load is studied as a function of the flame volume for different heat inputs. In this work, the flame emissivity is assumed constant and equal to 0.25 . Figure 1 shows the effect of the flame volume on the heat transfer rate from the flame to the load (heat sink). The enhancement of heat flux is increased with 
the flame volume at different heat inputs. It can be understood as: on the one hand, a larger flame volume leads to a larger flame area, which is favourable for the heat transfer. On the other hand, the flame temperature, $\mathrm{T}_{\text {flame }}$ decreases when the flame volume increases. This leads to a decrease of the heat radiation from the flame. Since the heat transfer from the wall to the heat sink occupies a larger proportion, the effect of flame area increase on the heat transfer plays a larger role than that of the flame temperature.

\section{General features of "flameless" oxyfuel combustion}

Oxidation reactions during "flameless" combustion as well as flame properties depend on the method of mixing between the oxidizer and fuel. From the oxidizer-fuel mixing point of view combustion process can be classified into three classes:

I. Combustion with high fraction of oxygen (up to 100\%) in the oxidizer directly mixed with fuel directly at neighbourhood of the burner outlet. Fuel mixes directly with the oxidiser and some small amount of flue gases (recirculation). The degree of the flue gas recirculation depends on the burner design. Combustion is very intensive and takes place inside a small volume. Because volumetric heat load is very high the flame is very well seen as it radiates intensively. The flame is stabilised aerodynamically and "attached" to the burner outlet.

II. Combustion with use of atmospheric air can be assumed as less intensive and taking place in a large volume. Also, in this case the fuel mixes directly with the oxidiser and some small amount of flue gases (recirculation). The degree of the flue gas recirculation depends also on the burner design. Volumetric heat load and intensity of radiation are lower because the flame is diluted by nitrogen present in air. Flame is less luminous with less visible borders also however stabilised aerodynamically and "attached" to the burner outlet. In such combustion air preheating up to $400-500^{\circ} \mathrm{C}$ is used and air or fuel staging is used for low $\mathrm{NO}_{\mathrm{x}}$ combustion effect.

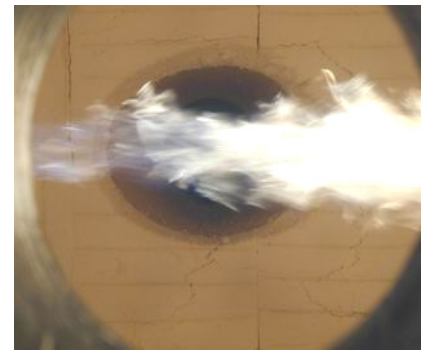

a)

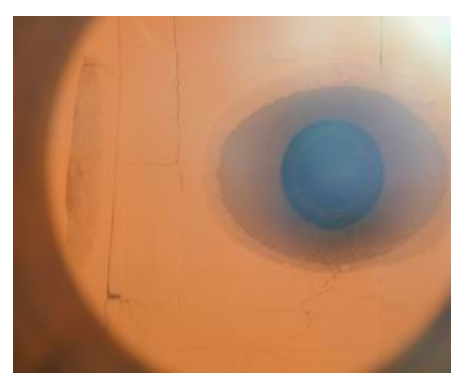

b)

Figure 2: Flame appearance during LPG combustion: a) conventional oxyfuel combustion b) "flameless" oxyfuel combustion [9]. 
III. Combustion in highly preheated air (above $1000^{\circ} \mathrm{C}$ ), in pure oxygen or in slightly preheated air enriched with oxygen characterised by even less intensive combustion taking place in very large volume. To obtain such combustion phenomena, the fuel and oxidiser should be injected separately in order to delay mixing. The degree of the flue gas recirculation is very high and consequently fuel is mixed with the oxidiser at very low level of oxygen concentration. Oxygen is diluted in the mixture of flue gases and air of high temperature. Volumetric heat load of the flame and its luminous radiation is very small and therefore the flame is often not visible ("flameless" combustion, Figure 2) but present, occupying a much larger volume of the furnace chamber compared to combustion phenomena described in points I and II. The flame is stabilised by means of temperature field and is not longer "attached" to the burner outlet. Often the flame is characterised as a "lifted flame".

\section{Development and study of the oxyfuel "flameless" combustion burner}

In order to realize a new mode of oxyfuel combustion that is "flameless", a new type of burner was built. The burner was subject of this study and results in a comparison with other burners are presented below.

Flameless Oxyfuel Combustion burner, $\mathrm{REBOX}^{\circledR}-\mathrm{W}$, is shown in Figure 3. This burner uses commercial oxygen as oxidizer and gives a flameless combustion in the furnace. The high velocity of oxygen at the exit of the nozzles causes excellent internal mixing and accounts for the flameless combustion. The features of this burner are: simple construction, operation and very small in size. The single-flame HiTAC (High Temperature Air Combustion) burner used for the study was a REGEMAT ${ }^{\circledR}$ burner. It is a REGEMAT ${ }^{\circledR} 350$ FLOX burner regenerative type that heats combustion air to $950^{\circ} \mathrm{C}$. For efficient extraction of the heat from the regenerators, there are two sets that get alternatively heated and cooled by passing of flue gases and combustion air respectively. This is done with a cycle time of 10 seconds. During operation, $80 \%$ of flue gas is extracted through the regenerator. This burner is characterized by a single flame created by one fuel nozzle, surrounded by air inlets and flue gas outlets. This single flame develops along the axis of the fuel-jet nozzle during cooling and heat periods of the regenerators. Fuel is supplied continuously through the same nozzle and in this way a single flame can be formed with a permanent position. This position remains almost unchanged between heating and cooling periods, as the regenerators are located around the nozzle. The effect of oxygen enhancement on a HiTAC burner was studied by adding oxygen to air in the REGEMAT ${ }^{\circledR}$ burner. The mole fraction of oxygen $(\Omega)$ in the oxidizer was $\Omega=29.2$.This is a retrofit arrangement. The conventional Oxyfuel combustion was carried out by modifications to the REBOX ${ }^{\circledR}-\mathrm{W}$ burner.

A cold air burner was used in the study. The data obtained was used as a reference and all sets of measurement were not performed as it exhibited far inferior performance in Comparison to the above burners. 


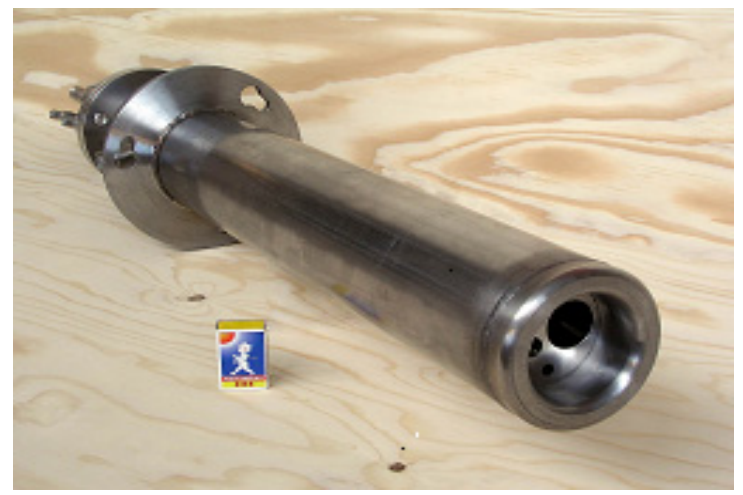

Figure 3: Burner $\left(\right.$ REBOX $^{\circledR}$ type) working according to oxyfuel "flameless" mode [16].

\subsection{Results of measurements: flame shape and flame volume}

To describe the flame boundary as per [10], the oxidation mixture ratio was defined according to equation (1). The oxidation mixture ratio allows estimating the combustion progress and can be calculated as mass fraction of oxygen to mass fraction of oxygen and the sum of oxygen needed to complete combustion at any point in combustion chamber, as follows:

$$
R_{o}=\frac{m_{O}}{m_{O}+\sum_{c} s_{o} m_{F, c}}
$$

where $s_{O}=n_{O} M_{O} / n_{F} M_{F}$. This ratio will have the value $R_{\mathrm{O}}=1$ when it is at air inlet or combustion is completed. Thus the flame volume defined by means of the oxidation mixture ratio was assumed to be inside the space limited by the following relationship:

$$
0<R_{\mathrm{O}} \leq 0.99
$$

For fuel inlet the $R_{\mathrm{O}}=0 . R_{\mathrm{O}}=0.99$ is assumed to indicate a flame border. Flame length was calculated as the distance between the burner's face and the axial location of the oxidation mixture ratio equal to 0.99 . The calculated length was REBOX $^{\circledR}$-W $1.833 \mathrm{~m}$, REGEMAT $^{\circledR} 1.534 \mathrm{~m}$, REGEMAT $^{\circledR}$-Enhanced $2.044 \mathrm{~m}$ and Conventional oxyfuel $1.379 \mathrm{~m}$.

\section{$5 \quad$ NO $_{x}$ reduction mechanism}

Most of NO generated during gas fuels combustion is from the high temperature of oxidation of atmospheric nitrogen. The NO formed is called "thermal NO" and its formation rate is an exponential function of flame temperature and a square root function of oxygen concentration. Thus, the formation of thermal NO can be controlled by controlling the flame temperature and the oxygen 
concentration. The main primary control strategies for reducing the formation of NO can be specified as follows:

- Stoichiometry based combustion control methods designed to control the mixing of fuel and oxidiser to reduce the concentration of oxygen in the flame zone,

- Dilution based combustion control methods designed to reduce the flame temperature in the flame zone by introducing inert gases.

For flameless combustion technology, the basic reason for thermal NO reduction is due to lower flame temperature and due to reduced oxygen concentration. The lower flame temperature is achieved by dilution of combustion zone with use of very intensive internal flue gas recirculation. It results also in bigger flame volume and thus also reduction of oxygen partial pressure. The $\mathrm{NO}_{\mathrm{x}}$ emissions are as low as $2 \mathrm{mg} / \mathrm{MJ}$ in case of oxyfuel flameless combustion realized by means of the REBOX ${ }^{\circledR}$ type burners.

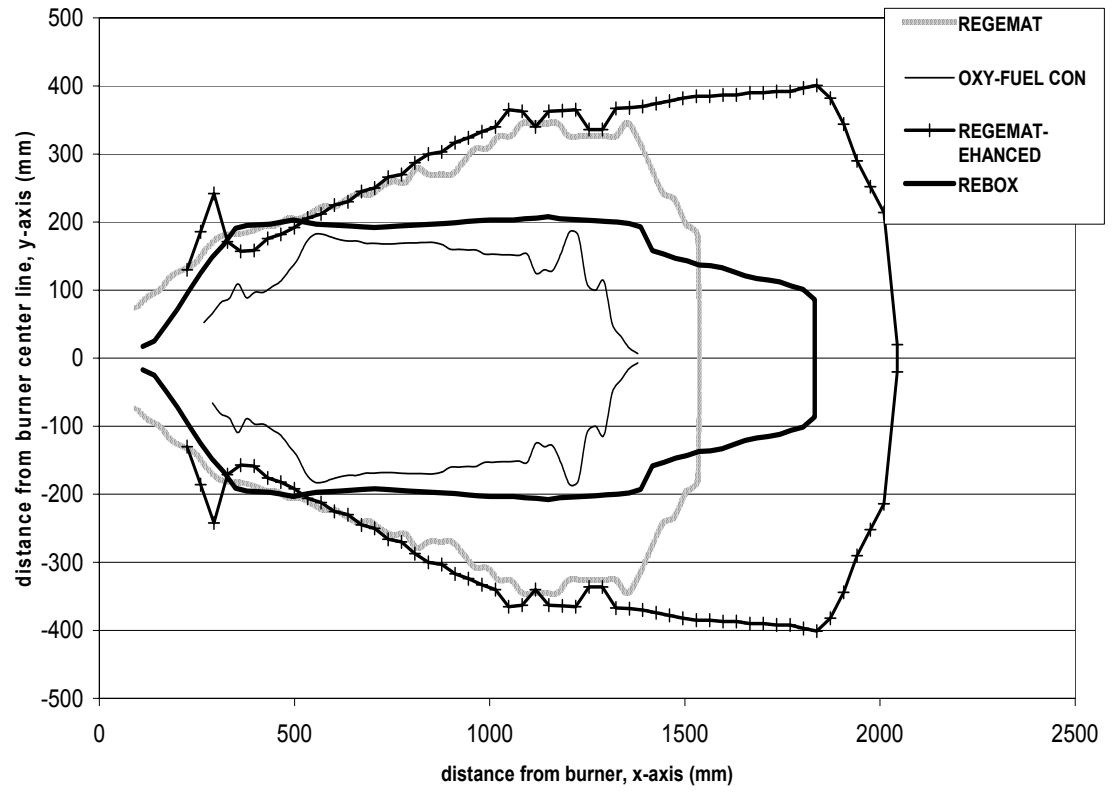

Figure 4: $\quad$ Flame boundary in the central plane across the furnace [11].

\section{Oxyfuel "flameless" combustion applied to incinerators}

Grate fired furnaces are still a widely used technology for solid fuel combustion. Because the mixing process is usually poor in the fuel bed on the grate and in the gas phase region above the grate, complete combustion in a conventional grate fired boiler or incinerator is difficult to achieve. Since clean combustion of wastes has become an essential task due to the more strict requirements for 
environmental protection, it is desirable to use oxyfuel flameless combustion systems to improve wastes combustion in grate-fired furnaces.

The control of flow pattern and mixing processes inside combustion chambers of waste incinerators is necessary to achieve efficient combustion with low emissions of pollutants. There are three main types of waste incinerators used to burn municipal solid wastes (MSW) and biomass wastes. These can be subdivided into grate firing incinerators, fluidized bed incinerators and fixed bed incinerators. Normally, the combustion chamber of the incinerator consists of a lower and an upper furnace. The lower furnace is used to mix wastes with primary combustion air and therefore is also called the primary combustion zone. Mixing processes between primary combustion air and wastes occur on the grate or in the fluidized bed.

The thermo chemical processes occurring inside the primary combustion zone produce bed-off gas, which then reacts in the upper furnace of the waste incinerator [2]. Chemical composition of the bed-off gas depends on the amount and temperature of primary air. The bed-off gas leaving the lower furnace must react efficiently in order to complete combustion, reduce $\mathrm{NO}$ and $\mathrm{SO}_{3}$ along the height of the upper furnace.

There are several ways to control mixing in the upper furnace e.g. changing the upper furnace geometry or controlling the mixing by means of number of nozzles placed on the walls of the upper furnace at various levels. The most common approach to complete combustion in the upper furnace and reduce pollutants $\left(\mathrm{NO}_{\mathrm{x}}, \mathrm{CO}\right.$ dioxins, furans and particulates) is using number of air nozzles placed on the walls at various levels called the multi-nozzle system. Low temperature air is commonly used although secondary high temperature air (above $1000^{\circ} \mathrm{C}$ ) has been already applied as well.

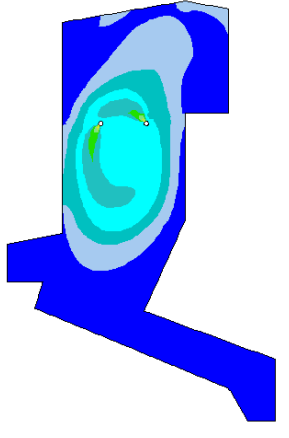

a.

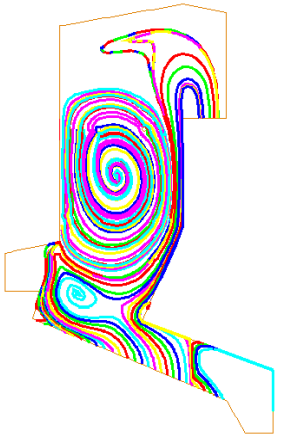

b.

Figure 5: Schematic idea of creation of oxyfuel flameless secondary combustion zone in municipal solid waste incinerator. A. Contours of mass fraction of oxygen B. Path lines after introduction of oxygen with use of perforated tubes [15].

Implementation of oxyfuel flameless second stage combustion (Figure 5) is an alternative that can dramatically improve performance of waste incinerators 
reducing all pollutants by controlling: temperature, residence time and stoichiometry. Use of well-stabilised large volume flameless combustion zone in the upper furnace of the waste incinerator will also stabilise thermal processes occurring in the bed of wastes on the grate. Oxygen could be for example injected with use of Ecotubes placed above the grate as schematically is shown in Figure 5 [14, 15].

\section{Summary}

Flameless oxyfuel combustion technology is characterised by: high efficiency, low formation of pollutants as $\mathrm{NO}_{x}, \mathrm{CO}$, soot, particulates. Flameless oxyfuel combustion is applied, with great success, in industrial installations including reheat and annealing furnaces at steel mills belonging to the following companies: Ascométal, Outokumpu Stainless, Scana Steel and Uddeholm Tooling. Additionally, this technology has been successfully installed for vessel pre-heating, for ladles and converters [16]. If applied as a secondary stage in waste incinerators it can be of great help to reduce not only $\mathrm{NO}_{\mathrm{x}}, \mathrm{CO}$ and particulates but also dioxins and furans. A large flame characterising the flameless combustion and high heat flux density is of great importance as well stabilising waste thermal decomposition in the primary combustion zone on the grate or in fluidised bed.

\section{References}

[1] Baukal C. E., Oxygen-Enhanced Combustion, CRC Press LLC, 1998, ISBN 0-8493-1695-2

[2] Rudnicki Z., Radiacyjny przepływ ciepła w piecach przemysłowych, Wydawnictwo Politechniki Śląskiej, Gliwice 1998.

[3] Blasiak W., Yang W., Wikström P., Jiang S., Heat transfer enhancements for energy savings in industrial furnaces, ISRN KTH/MSE-05/12SE+ENERGY/RAPP, Stockholm, May 2005.

[4] Blasiak W., Yang W., Rafidi N., Physical properties of a LPG flame with high-temperature air on a regenerative burner, Combustion and Flame 136 pp: 567-569, Published by Elsevier Inc. (2004).

[5] Yang W., Blasiak W., Chemical flame length and volume in LPG combustion using high temperature and low oxygen concentration oxidizer, Energy and Fuels, Vol.18, 2004, pp. 1329-1335.

[6] Tsuji, H., Gupta, A.K., Hasegawa, T., Katsuki, M., Kishimoto, K., Morita, M., High Temperature Air Combustion, From Energy Conservation to Pollution Reduction, CRC Press LLC, New York, 2003

[7] Blasiak, W., Szewczyk, D., Mörtberg, M., Rafidi, N., Yang W., Combustion Tests in a Test Furnace Equipped With High Temperature Air Combustion Mode, Industrial Heating Journal, ISSN 0454-1499, Vol. 41 (2), pp 66-73, Japan 2004.

[8] Blasiak W., Narayanan K., Yang W., Evaluation New Combustion Technologies for $\mathrm{CO} 2$ and $\mathrm{NO}_{\mathrm{x}}$ Reduction in Steel Industries, Air 
Pollution 2004, Twelfth International Conference on Modelling, Monitoring and Management of Air Pollution, 30 Jun -2 July 2004, Rhodes, Greece.

[9] Yang W., Blasiak W., Ekman T., Numerical and thermodynamic study on oxyfuel flameless combustion, $8^{\text {th }}$ International Conference on Energy and Clean Environment, Clean Air 2005, Lisbon, 27-30 June, 2005

[10] von Schéele J., Blasiak W., Oxyfuel solutions for lowered environmental impact of steel production, International Conference on Clean Technologies in the Steel Industry, 6-8 June, 2005, Balatonfüred, Hungary

[11] Narayanan K., Yang, W., Ekman T., Blasiak W., Combustion characteristics of flameless oxyfuel and oxygen-enriched-High Temperature Air Combustion, $6^{\text {th }}$ HiTACG 2005, Sixth International Symposium on High Temperature Air Combustion and Gasification, 1719 October 2005, Essen, Germany.

[12] von Schéele J., Vesterberg P, Ritzen O, Invisible Flames for Clearly Visible Results, Nordic Steel \& Mining Review, pp 16 -18, 2005

[13] Kobayashi H, Boyle J.G., Keller J.G., Patton J.B., Jain R.C., Technical and economic evaluation of oxygen enriched combustion systems for industrial furnace applications, pp. $153-163$

[14] Blasiak W., W Yang., Combustion improvement system in boilers and incinerators, International Joint Power Generation Conference, IJPGC'03, June 16-19, 2003 (paper IJPGC2003-40141), Atlanta, Georgia, USA

[15] Blasiak W., Fakhrai R., Residence time and mixing control in the upper furnace of boilers and incinerators, International Conference on Incineration and Thermal Treatment Technologies, IT3, May 13-17, 2002, New Orleans, Louisiana, USA

[16] REBOX, http://www.rebox.info 